\title{
SENTRA KERAJINAN KULIT DI KEMANG
}

\author{
Anita Darmawan ${ }^{1)}$, Timmy Setiawan²) \\ 1)Program Studi S1 Arsitektur, Fakultas Teknik, Universitas Tarumanagara, anita_darmawan@ymail.com \\ ${ }^{2)}$ Program Studi S1 Arsitektur, Fakultas Teknik, Universitas Tarumanagara, timmy@unitricipta.com
}

\begin{abstract}
Abstrak
Kerajinan (kriya) adalah salah satu dari tiga subsektor yang kontribusinya cukup signifikan dalam perkembangan industri ekonomi kreatif dan pelaku industri kreatif paling banyak dari generasi milenial. Seni kriya merupakan salah satu sub sektor yang menjadi ciri khas Bangsa Indonesia. Kerajinan kulit merupakan salah satu bahan baku material seni kriya yang banyak diminati kalangan milenial. Kerajinan kulit Indonesia di era kekinian semakin beragam. Namun persoalan dari pengembangan ekonomi kreatif dan startup adalah kebutuhan modal dan pemasaran. Adanya kendala tersebut menyebabkan startup tidak dapat berkembang maksimal. Proyek ini merupakan wadah untuk pengerajin kulit berkreasi dengan menggabungkan sarana pendidikan informal dan ruang pameran. Kegiatan ini dimaksudkan untuk saling mendukung sehingga pengerajin kulit dapat langsung memamerkan hasil karyanya dan dapat langsung dilihat dan dibeli oleh konsumen. Konsumen juga sekaligus dapat melihat proses pengerjaannya dan belajar membuat. Proyek berada di Kemang yang dikenal secara internasional sebagai kawasan industri kreatif dimana banyak generasi milenial berkumpul. Serta berpotensi dalam perkembangan infrastrukturnya. Dengan adanya proyek ini selain mendatangkan keuntungan finansial dari karya ide dan inovasi produk berbahan dasar kulit, juga diharapkan membangun dan membangkitkan generasi milenial, selaku pelaku utama, untuk membentuk komunitas yang memiliki tujuan untuk berkumpul serta berbagi pengalaman dan wawasan mengenai kecintaan mereka tentang kerajinan kulit. Kegiatan ini menjadikan generasi milenial aktif dan kreatif untuk bersosialisasi dalam kalangan masyarakat luas melalui kerajinan kulit. Selain itu proyek ini dibuat untuk meningkatkan apresiasi masyarakat baik yang tertarik dibidangnya maupun orang awam yang datang terhadap nilai produk-produk berbahan dasar kulit dengan mengamati proses pembuatan produknya.
\end{abstract}

Kata kunci: industri kreatif; kerajinan kulit; milenial

\begin{abstract}
Handcraft is one of three sub-sectors whose contribute significantly to the development of creative economic industry growth. The most creative industry figure are from the millennial generation. Handcraft art is one of the sub-sectors that is represents the characteristic of the Indonesian nation. Leather craft is one of the raw materials for craft arts that is greatly demand by millennials. In the present, Indonesian leather crafts are increasingly diverse. But the problem of developing a creative economy and startup is capital needs. The problem causes startups to not be able to develop optimally. This project is a forum for creative craftsmen by combining informal educational facilities and exhibition halls. This activity is intended to support each other so that leather craftsmen can immediately showcase their work and can be directly seen and bought by consumers. Consumers can simultaneously see the process and learn how to make it. The project is located in Kemang which is known internationally as a creative industrial area where many millennial generations gather. And the potential for infrastructure development. With this project in addition to bringing financial benefits from the work of ideas and innovation made from leather-based products, it is also expected to build and generate millennial generations, as the main actors, to form communities that aim to gather and share experiences and insights about their love of leather crafts. This activity makes the millennial generation active and creative to socialize in the wider community through leather crafting. In addition, this project was created to increase the appreciation of the community, both those who are interested in their fields and lay people who come to the value of leather-based products by observing the process of making their products.
\end{abstract}

Keywords: creative industry; leather; millennial 


\section{PENDAhUluAN}

Jakarta sebagai ibukota memiki peran penting dalam sistem perekonomian Indonesia. Pergerakan motor ekonomi utama terjadi di Jakarta. Sudah sepantasnya Jakarta memberikan sumbangsih pendapatan terbesar bagi negara. Sektor pendapatan negara yang mampu memberikan kontribusi ekonomi yang signifikan dan sangat prospektif adalah sektor yang berbasis kreatif. Dengan memaksimalkan potensi serta kekhasan dan keunikan suatu tempat atau barang atau kebudayaan, dapat mendatangkan peminat yang besar baik lokal maupun mancanegara. Selain itu juga dapat menciptakan Iklim bisnis yang positif, membangun citra dan identitas bangsa, berbasis kepada sumber daya yang terbarukan, menciptakan inovasi dan kreativitas yang merupakan keunggulan kompetitif suatu bangsa, serta memberikan dampak sosial yang positif.

Industri kreatif di Indonesia beberapa tahun terakhir sedang berkembang pesat terbukti dengan adanya data bahwa jumlah industri kreatif lebih besar dari jumlah penduduk Indonesia, yaitu sekitar 300 juta unit-unit influence usaha kreatif. Sedangkan, jumlah UMKM (Usaha Kecil, Mikro dan Menengah) pada tahun 2017 menembus 60 juta, dan telah naik 3,1\% dari penduduk Indonesia. Pertumbuhan tersebut karena didorong dari semangat generasi milenial dalam menciptakan usaha. Generasi millenial cenderung sangat kreatif, percaya diri, dan lebih suka mengejar passion serta totalitas dalam menjalaninya. Inilah salah satu alasan kenapa pertumbuhan industri kreatif tumbuh sangat cepat. Melihat pertumbuhan industri kreatif yang berpotensi bisa berkembang di Indonesia. Maka tidak ada yang tidak mungkin, bahwa nantinya industri kreatif bisa memasuki pasar dunia, dan ekspor industri kreatif yang akan mengalami peningkatan setiap tahunnya. Keyakinan yang ada karena industri kreatif saat ini di dominasi anak muda generasi milenial yang memiliki segudang kreativitas, kemajuan teknologi yang mendukung berkembangnya bisnis.

Kerajinan tangan atau biasa disebut kriya merupakan salah satu sub sektor industri kreatif yang saat ini memberikan kontribusi yang cukup signifikan dalam perkembangan industri kreatif di Indonesia. Seni kriya juga merupakan industri kreatif yang menjadi ciri khas bangsa Indonesia. Banyak kerajinan yang dapat dibanggakan dari Indonesia, bahkan tidak jarang hasilnya sudah dikenal di mancanegara. Barang-barang tersebut antara lain: kerajinan batik, kerajinan tenun, kerajinan ukir, kerajinan kulit, kerajinan keramik, dan masih banyak lagi hasil karya UKM Indonesia yang sebenarnya memiliki nilai jual yang tinggi jika dapat mengembangkan dan meningkatkan nilai jualnya.

Di Indonesia, kulit merupakan salah satu bahan mentah yang cukup melimpah, yang digunakan sebagai bahan baku utama dalam industri kerajinan kulit. Permasalahan utama yang membuat pengerajin kulit kurang mendapat motivasi dan kurang memaksimalkan kinerjanya adalah permasalah permodalan. Kurangnya modal dalam indutri kerajinan kulit mengakibatkan tidak dapat memenuhi kebutuhan pokok seperti: biaya produksi, tempat kerja, serta tidak dapat mengikuti perkembangan teknologi. Selain itu juga kurangnya pemasaran barang produksi kerajinan kulit itu sendiri sehingga kurang dikenal baik lokal maupun mancanegara.

Seharusnya jika semua elemen dapat saling bersinergi dan berkerjasama, potensi usaha kerajinan kulit Indonesia ini akan memiliki peluang yang cukup besar. Maka dari itu, proyek yang diusulkan adalah sentra kerajinan kulit yang merupakan wadah untuk para pekerja industri kerajinan kulit berkerja dan berkomunitas berupa ruang kerja dan fasilitas pendukungnya. Area pameran untuk memasarkan produk-produk kerajinan kulit sehingga dapat menjembatani antara konsumen dan produsen. Dan pada akhirnya dapat meningkatkan apresiasi masyrakat terhadap kerajinan kulit dan produk dalam negeri.

Lokasi tapak berada di kawasan Kemang, Jakarta Selatan yang strategis karena terletak di jalan utama kawasan Kemang yang merupakan sebuah daerah yang dikenal secara internasional yang berorientasi menyediakan fasilitas seperti toko kerajinan tradisional, tempat makan, dan tempat nongkrong. Sehingga banyak orang-orang kalangan generasi milenial berkumpul baik lokal maupun mancanagara. Dengan hadirnya sentar kerajinan kulit di 
kemang dapat melengkapi identitas Kemang sebagai kawasan industri kreatif dan memiliki potensi wisata yang tinggi.

Diharapkan melalui proyek ini dapat menjadikan kawasan Kemang serta Jakarta yang lebih berkarakter melalui generasi milenial dalam mengembangkan ekonomi, sosial, dan budaya dalam bidang industri kreatif kerajinan kulit.

\section{KAJIAN LITERATUR}

\section{Generasi Milenial}

Generasi milenial adalah nama lain dari generasi $Y$, generasi yang lahir antara tahun 19811994. Saat ini, generasi milenial berada pada usia produktif dan mereka yang akan menjadi tulang punggung perekonomian Indonesia.

Menurut data badan Pusat Statistik (BPS), jumlah penduduk Indonesia usia 20 hinga 40 tahun di tahun 2020 diperkirakan berjumlah 83 juta atau 34\% dari total penduduk Indonesia yang mencapai 271 juta jiwa. Proporsi tersebut labih besar dari proporsi generasi $\mathrm{X}$ yang sebesar 53 juta jiwa (20\%) dan generasi baby boomer yang berjumlah 35 juta jiwa (13\%). Sehingga pada tahun 2020, mereka akan dalam usia produktif dan terbanyak dan mereka yang akan menjadi tulang punggung perekonomian Indonesia.

\section{Generasi Milenial di DKI Jakarta}

Berdasarkan proyeksi pertumbuhan penduduk yang dilakukan Badan Perencanaan Pembangunan, Badan Pusat Statistik dan United Pupulation Fund jumlah penduduk DKI Jakarta mencapai 10,47 juta jiwa. Jumlah tersebut terdiri dari 5,22 juta jiwa perempuan dan 5,24 juta jiwa laki-laki. Menurut kelompok umur, penduduk yang berusia antara 30-34 tahun (generasi milenial) merupakan yang terbanyak, yakni mencapai 1 juta jiwa atau sekitar $10 \%$ dari total populasi di Ibu Kota. Kelompok usia produktif, menurut BPS adalah mereka yang berusia antara 15-64 tahun. Sehingga jumlah penduduk usia produktif di DKI Jakarta pada tahun ini: diprediksi mencapai 7,46 juta jiwa atau sekitar $71 \%$ dari total populasi. Jadi, generasi milenial menduduki jumlah penduduk terbanyak di Jakarta dan mereka yang akan menjadi tulang punggung perekonomian Jakarta dan Indonesia.

Setiap generasi memiliki karakteristik yang berbeda-beda namun tetap memiliki ciri khasnya masing-masing. Generasi milenial adalah generasi yang unik, hal ini banyak dipengaruhi oleh munculnya smartphone, meluasnya internet, dan munculnya jejaring sosial media. Ketiga hal ini banyak mempengaruhi pola piker, nilai-nilai, dan prilaku generasi milenial.

\section{Karakteristik Generasi Milenial}

Karakteristik generasi milenial beragam tergantung dari faktor sosial dan lingkungan yang berubah setiap saat. Menurut Hasanuddin Ali, CEO Alvara Research, generasi milenial memiliki tiga karakter utama, yaitu:

- Connected atau koneksi karena mereka ialah pribadi yang pandai bersosialisasi terutama dalam komunitasnya. Generasi milenial sangat aktif menggunakan medsos. Rata-rata setiap lima menit sekali mereka menengok internet atau telepon selulernya.

- Creative atau kreatif yang mana generasi milenial merupakan orang-orang yang berpikir out of the box, kaya akan ide dan gagasan, serta mampu mengomunikasikan ide dan gagasan mereka dengan baik. Mereka boleh dikatakan sebagai generasi kreatif. Sebagai bukti, saat ini industri kreatif yang dimotori anak-anak muda berkembang pesat.

- Confidence atau kepercayaan diri yang mana generasi milenial ialah orang-orang yang sangat percaya diri, berani mengemukakan pendapat, dan tidak sungkan berdebat melalui medsos.

Ketiga karakteristik tersebut sangat berpengaruh pada perilaku mereka sehari-hari. Misalnya, mereka lebih percaya pada informasi yang sifatnya interaktif, lebih memilih ponsel ketimbang menonton televisi, dan cenderung tidak loyal terhadap tempat bekerja. 


\section{Tipe, Prilaku, dan Milenial dalam Arsitektur}

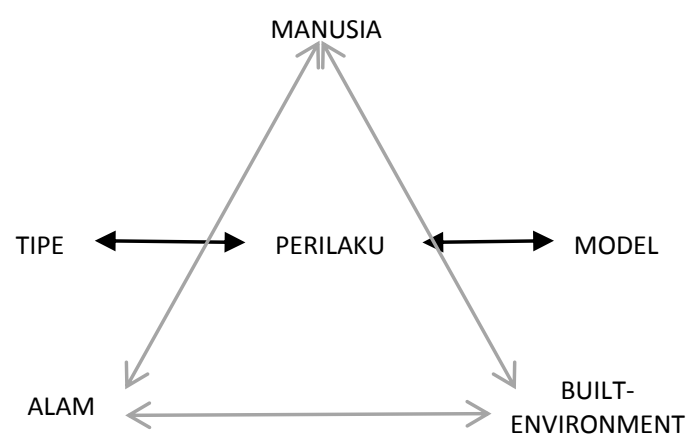

Gambar 1. Diagram Keterkaitan Tipe, Perilaku, Model

Sumber: Tsukamoto, 2010

Dalam karya Typological Urbanism, Christoper Lee dan Sam Jacoby membagi tipe dalam dua bentuk dasar, yakni tipe berupa model dan tipe berupa ide. Quatremere de Quincy dalam Encyclopedie Methodique (1825), menegaskan bahwa tipe tidak merepresentasikan tiruan dari suatu bentuk, melainkan ide dari sebuah elemen yang memberikan aturan bagi bentukan model, sementara model adalah objek yang bahrus diulang sebagaimana bentuknya.

Menurut Tsukamota dan Kaijima, perilaku merupakan cara seseorang atau sesuatu bertindak terhadap subjek atau objek disekitarnya. Perilaku dapat menjadi dasar dari sebuah hipotesa untuk memahami ketersinambungan antara manusia, alam dan lingkungan bangunan. Pada diagram diatas, tidak selalu tipe menghasilkan model namun bisa juga model menghasilkan tipe lalu menghasilkan sebuah perilaku. Prosesnya berbeda, berdasarkan terjadinya secara sadar maupun tidak sadar dan terbentuk secara kolektif atau melalui peran arsitek. Pada Tugas Perancangan 8.27 ini perilaku generasi milenial yang menjadi perhatian utama dalam menentukan program arsitektur, hingga akan menghasilkan program yang mampu mewadahi aktivitas dan kegiatan tersebut.

\section{Industri Kreatif}

Industri kreatif dapat diartikan sebagai kumpulan aktivitas ekonomi yang terkait dengan penciptaan atau penggunaan pengetahuan dan informasi. Industri kreatif juga dikenal dengan nama lain Industri Budaya (terutama di Eropa) atau juga Ekonomi Kreatif. Kementerian Perdagangan Indonesia menyatakan bahwa Industri kreatif adalah industri yang berasal dari pemanfaatan kreativitas, keterampilan serta bakat individu untuk menciptakan kesejahteraan serta lapangan pekerjaan dengan menghasilkan dan mengeksploitasi daya kreasi dan daya cipta individu tersebut.

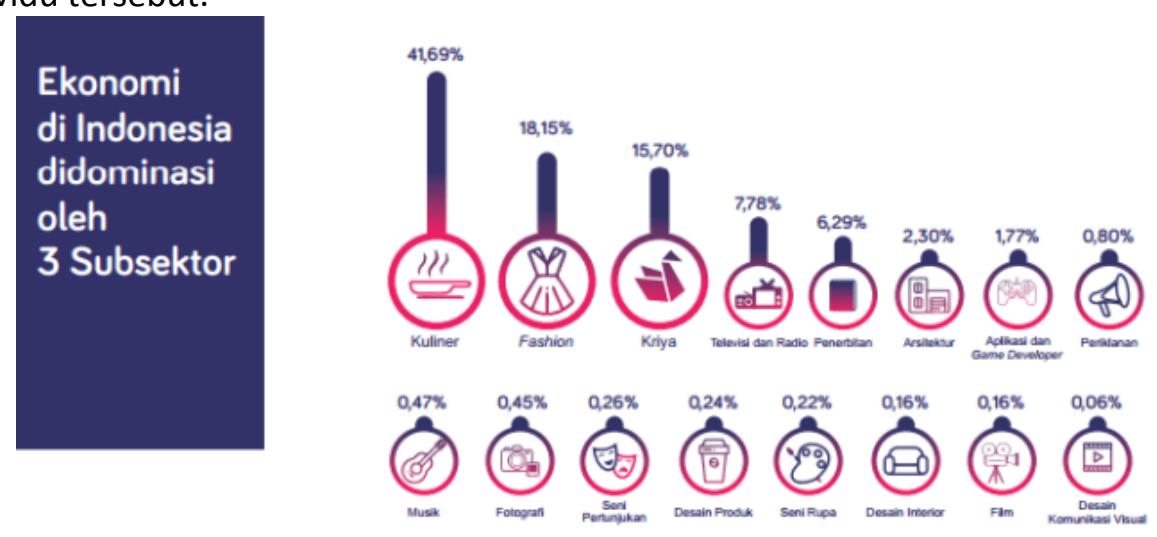

Gambar 2. Kontribusi PDB Ekonomi Kreatif Berdasarkan 16 Subsektor pada 2016 Sumber: Hasil Survei Khusus Ekonomi Kreatif oleh Berkaf dan BPS, 2016 
Dari potensi ekonomi kreatif saat ini, baru tiga subsektor yang berkontribusi cukup signifikan dalam perkembangan dan pertumbuhan ekonomi kreatif yaitu kuliner, fashion dan kerajinan (kriya). ketiganya merupakan bagian dari 16 subsektor ekonomi kreatif yaitu arsitektur, desain interior, desain komunikasi visual, desain produk, film animasi dan video, fotografi, kriya, kuliner, music, fesyen, aplikasi dan game, penerbitan, periklanan, televisi dan radio, seni pertunjukan, dan seni rupa.

\section{Kerajinan}

Indonesia sudah dikenal dikenal dengan banyak kerajinan-kerajinan yang terus berkembang hingga saat ini. Di antaranya yaitu kerajinan batik, kerajinan logam, kerajinan kayu, kerajinan kulit, dan masih banyak lagi macam-macam kerajinan yang tersebar di penjuru wilayah Indonesia. Tidak dipungkiri, sebagian penduduk Indonesia dalam suatu wilayah banyak yang menggantungkan hidupnya dari membuat produk-produk kerajinan yang mengandalkan keterampilan tangan mereka. Menurut Raharjo (2009: 200), kerajinan adalah suatu hal yang bersifat rajin, mengacu pada kegiatan atau kegetolan yang berwujud barang yang dihasilkan melalui keterampilan tangan. Dalam Kamus Besar Bahasa Indonesia (1990: 722), kerajinan berarti perihal rajin; kegiatan; kegetolan; industri; perusahaan; membuat sesuatu. Sedangkan dalam Ensiklopedi Indonesia (1982: 1749), arti kerajinan tangan ialah jenis kesenian yang menghasilkan berbagai barang perabot; hiasan; atau barang-barang lain yang artistik; terbuat dari kayu, besi, porselin, emas, gading, katun, tenun, dan sebagainya. Umumnya, barangbarang hasil kerajinan banyak dikaitkan dengan unsur seni yang kemudian disebut sebagai seni kerajinan (KBBI, 2007: 922). Seni kerajinan adalah implementasi dari karya seni kriya yang telah diproduksi secara 8 massal oleh para perajin (Raharjo, 2009: 200).

\section{Kerajinan Kulit dan Jenis-Jenis Kulit}

Pengertian kulit di Kamus Besar Bahasa Indonesia (1990: 473) yaitu, pembalut paling luar tubuh (manusia, binatang); pembalut biji; pembalut tubuh binatang yang telah dikeringkan; bagian kitab atau buku; biasanya lebih tebal; dan segala sesuatu yang tampak di luar. Sedangkan dalam ilmu biologi, kulit merupakan lapisan paling luar pada organisme bersel banyak (Ensiklopedi 13 Indonesia, 1983: 1910). Sejalan dengan pengertian di atas, dalam kerajinan kulit, yang di maksud dengan kulit ini adalah kulit hewan, bukan kulit tumbuhan atau kulit manusia (Zuhdi, 2016: 2). Menurut Sunarto (2001: 9) kulit adalah lapisan luar tubuh binatang yang merupakan suatu kerangka luar, tempat bulu binatang itu tumbuh. Di Indonesia, kulit merupakan salah satu bahan mentah yang cukup melimpah, yang digunakan sebagai bahan utama dalam industri perkulitan dan karya seni. Kulit dihasilkan dari binatang ternak, sehingga selama orang masih memelihara atau memanfaatkan dan mengkonsumsi daging binatang ternak tersebut, kulit akan tetap tersedia. Saraswati (1996: 1) berpendapat yang di maksud dengan kulit ialah kulit binatang yang telah dijadikan atau diperindah serta diawetkan. Adapun Sunarto (2008: 6) menjelaskan bahwa kulit merupakan suatu tenunan dari tubuh hewan yang berbentuk dari sel-sel hidup, yang merupakan satu kesatuan saling mengikat. Sunarto (2008: 6) menjelaskan dalam bukunya, bahwa jenis kulit dapat dibedakan berdasarkan asal binatang, seperti misalnya kulit sapi Madura akan 16 berbeda dengan kulit sapi Fries Holland. Aktivitas hewan pada masa hidupnya juga berpengaruh terhadap kulit yang dihasilkan, seperti kulit sapi perah berlainan dengan kulit sapi potong. Selain itu Saraswati (1996: 5) mengemukakan bahwa kulit dapat dibedakan jenisnya menurut kualitas. Kualitas kedua sedikit lebih buruk daripada kulit dengan kualitas pertama, biasanya kulit kualitas kedua disebabkan bagian permukaan kulit mengalami kerusakan seperti luka pada waktu binatang itu masih hidup atau kurang baik dalam pemeliharaan. Sedangkan untuk kulit kualitas ketiga mempunyai kesalahan-kesalahan lebih besar seperti lubang, noda-noda, bagian-bagian yang kasar yang ditimbulkan karena penyakit atau pemeliharaan yang kurang baik. Setiap kulit binatang dari jenis yang berbeda, mempunyai sifat dan karakter yang berbeda pula. Oleh karena itu, dalam bukunya Sunarto (2001: 10) dapat disimpulkan bahwa kulit binatang dapat 
dibedakan kualitasnya menurut faktor-faktor berikut, (1) macam/jenis binatang ternak; (2) area geografi asal ternak; (3) aktivitas ternak; (4) masalah kesehatan ternak; (5) usia ternak. Berdasarkan faktor-faktor tersebut di atas, tidak semua kulit binatang memenuhi persyaratan sebagai bahan baku industri perkulitan, terutama dalam industri yang menggunakan bahan kulit alami.

\section{METODE}

Sentra Kerajinan Kulit tidak hanya sebagai wadah untuk pengerajin kulit berkreasi (studio kulit), namun digabungkan dengan sarana pendidikan informal atau pelatihan (workshop) dan ruang pameran. Kegiatan ini dimaksudkan untuk saling mendukung sehingga pengerajin kulit dapat langsung memamerkan hasil karyanya dan dapat langsung dilihat dan dibeli oleh konsumen. Konsumen juga sekaligus dapat melihat proses pengerjaannya dan belajar membuat. Studio kulit merupakan program utama dalam bangunan yang ditujukan untuk para pengerajin yang mayoritas adalah generasi milenial sehingga dirancang sedemikian rupa sehingga sesuai dengan cara kerja generasi milenial saat ini.

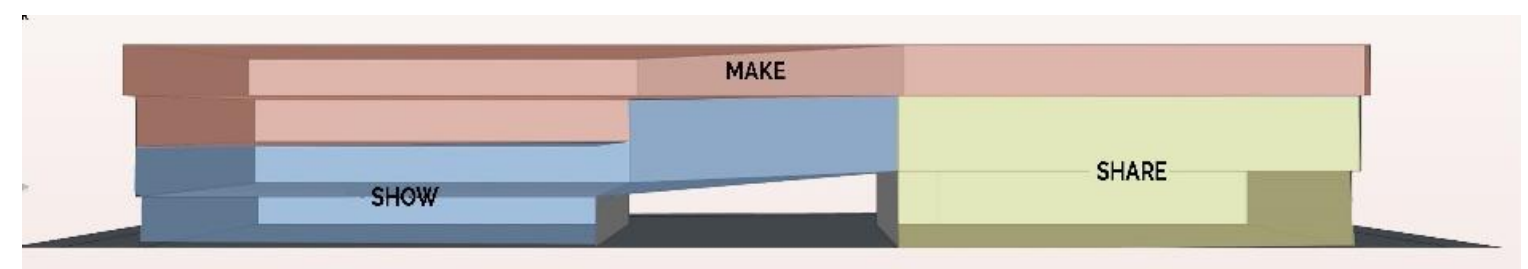

Gambar 3. Sistem Zonasi dalam Bangunan

Sumber: Penulis, 2019

Metode perancangan dengan sistem zonasi antar program dan lingkungan sekitar. Ada tiga program utama yaitu show, share, dan make:

- Show terletak di area yang paling terlihat dari segala arah untuk merepresentasikan bangunan sebagai sentra kerajinan kulit.

- Share merupakan area publik, terletak di area paling depan sehingga mengundang pengunjung dan pejalan kaki untuk masuk ke dalam bangunan. Area ini juga dapat dijadikan sebagai titik bertemu. Di area ini terdapat program-program untuk publik.

- Make merupakan area produksi atau pembuatan kerajinan tangan itu sendiri.

Tiap programnya berkesinambungan sehingga menjadi siklus yang menerus.

\section{DISKUSI DAN HASIL}

\section{Pengenalan Kawasan}

DKI Jakarta sebagai ibukota merupakan harapan bagi sejuta impian, dengan statusnya sebagai ibukota memberikan peluang usaha serta investasi yang besar dibandingkan kota-kota lain. DKI Jakarta secara administratif dibagi menjadi lima yaitu Jakarta Pusat, Jakarta Selatan, Jakarta Barat, Jakarta Timur, dan Jakarta Utara. Setiap bagiannya memiliki peran dan ciri khasnya masing-masing. Menurut data, Jakarta Selatan merupakan kota terluas ketiga di Provinsi DKI Jakarta dengan luas sekitar $141,3 \mathrm{~km}^{2}$ dengan jumlah penduduk sebanyak 2.185.710 jiwa (2015), dengan kepadatan $15.471,86 \mathrm{jiwa} / \mathrm{km}^{2}$. 


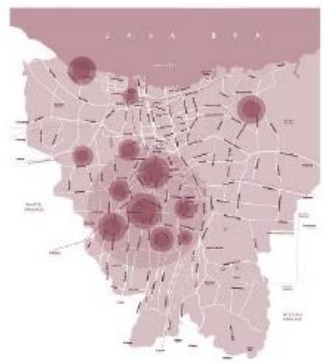

Area Nongkrong



Area Perkantoran

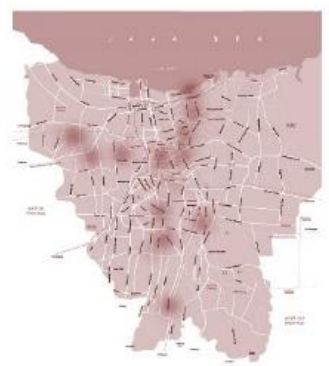

Art gallery and Creative Hub

\section{Gambar 4. Analisa Makro Jakarta}

Sumber: Penulis, 2019

Dari pemetaan kota Jakarta berdasarkan area nongkrong, area perkantoran, dan area dimana banyak galeri seni dan creative hub, dapat disimpulkan titik terbanyak berada di Jakarta Selatan. Jakarta Selatan adalah salah satu bagian dari kota Jakarta yang menjadi favorit dan dapat dibilang paling hits untuk generasi milenial karena selain sebagai pusat perkantoran, Jakarta Selatan identik dengan banyaknya galeri dan toko barang unik, restoran, tempat nongkrong, bar, hingga kafe-kafe yang berinterior fotogenik. Jadi selain banyak hal yang dapat memanjakan generasi milenial juga menjadi tempat favorit untuk berkarya dan berkerja.

\section{Analisa Meso}

Penulis melakukan pemetaan Jakarta Selatan berdasarkan infrastrukturnya, area perkantoran untuk menentukan titik keramaian dan pusat bisnis di Jakarta Selatan, pemetaan galeri seni, dan toko-toko kerajinan tangan produk lokal yang ada di Jakarta Selatan.



Infrastruktur



Area Perkantoran

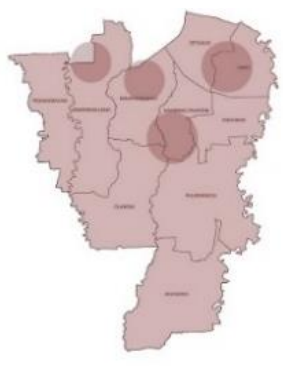

Art Gallery

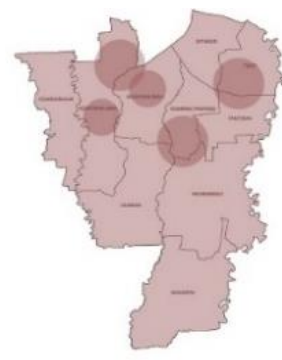

Local Art/Craft Store

Gambar 5. Analisa Mikro

Sumber: Penulis,2019

Berdasarkan pemetaan diatas, dapat disimpulkan Penyebaran industri kreatif terbanyak terdapat di sekitar kawasan Mampang Prapatan sehingga kawasan terpilih yaitu di Kemang. 


\section{Analisa Pelaku Kegiatan}

Tabel 1. Analisa Pelaku Kegiatan

\begin{tabular}{|c|c|c|c|}
\hline $\begin{array}{l}\text { Kategori } \\
\text { Pelaku }\end{array}$ & $\begin{array}{l}\text { Pelaku } \\
\text { Kegiatan }\end{array}$ & Keterangan & Kegiatan \\
\hline \multirow[t]{3}{*}{ Pengunjung } & $\begin{array}{l}\text { Wisatawan } \\
\text { Lokal }\end{array}$ & $\begin{array}{l}\text { Wisatawan dalam kota, berkunjung untuk } \\
\text { menikmati karya kerajinan kulit, berbelanja, dan } \\
\text { belajar }\end{array}$ & \multirow{3}{*}{$\begin{array}{l}\text { Menikmati karya } \\
\text { Berbelanja } \\
\text { Belajar } \\
\text { Berfoto } \\
\text { Makan } \\
\text { Nongkrong } \\
\text { Toilet }\end{array}$} \\
\hline & $\begin{array}{l}\text { Wisatawan } \\
\text { Luar Kota }\end{array}$ & $\begin{array}{l}\text { Wisatawan dari luar Jakarta, berkunjung untuk } \\
\text { menikmati karya kerajinan kulit, berbelanja, dan } \\
\text { belajar }\end{array}$ & \\
\hline & $\begin{array}{l}\text { Wisatawan } \\
\text { Asing }\end{array}$ & $\begin{array}{l}\text { Wisatawan dari luar negeri, dating karena rasa } \\
\text { ingin tau dan berbelanja }\end{array}$ & \\
\hline \multirow[t]{5}{*}{ Pengelola } & $\begin{array}{l}\text { Pengelola } \\
\text { Gedung }\end{array}$ & $\begin{array}{l}\text { Mengatur pemasaran dan managemen } \\
\text { pemakaian gedung }\end{array}$ & \multirow{5}{*}{$\begin{array}{l}\text { Dokumentasi } \\
\text { Penataan } \\
\text { Pemasaran } \\
\text { Kurasi } \\
\text { Toilet } \\
\text { Pengaturan sampah }\end{array}$} \\
\hline & $\begin{array}{l}\text { Pengelola } \\
\text { Umum }\end{array}$ & Mengatur kebersihan dan perawatan gedung & \\
\hline & $\begin{array}{l}\text { Pengelola } \\
\text { Studio }\end{array}$ & Mengatur pemakaian dan kegiatan di studio & \\
\hline & $\begin{array}{l}\text { Pengelola } \\
\text { Pameran }\end{array}$ & Mengatur kegiatan dan kurasi karya & \\
\hline & $\begin{array}{l}\text { Pengelola } \\
\text { Sampah }\end{array}$ & Pengatur pemilahan dan pengumpulan sampah & \\
\hline Pekerja & $\begin{array}{l}\text { Pengerajin } \\
\text { Kulit }\end{array}$ & $\begin{array}{l}\text { Menciptakan produk kulit yang akan dipamerkan } \\
\text { dan dijual }\end{array}$ & $\begin{array}{l}\text { Makan } \\
\text { Berkerja } \\
\text { Toilet }\end{array}$ \\
\hline
\end{tabular}

Sumber: Penulis, 2019

\section{Sasaran}

Sasaran utama dari Sentra Kerajinan Kulit ini merupakan generasi milenial yang memiliki atau ingin membuka usaha kecil menengah dalam bidang kerajinan kulit yang produktid dengan pola piker kreatif, selaku penjual maupun produsen. Tidak menutup kemungkin juga untuk orang-orang yang sudah bekerja namun tetap ingin berkarya sesuai dengan minat dan bakatnya dalam bidang kerajinan kulit. Sasaran lainnya adalah orang-orang yang tidak memiliki pekerjaan atau pengangguran untuk terlibat aktif dalam kegiatan pelatihan dan pengembangan dalam pasar industri ekonomi kreatif yang diciptakan.

\section{Konsep Perancangan}

Tabel 2. Program Ruang

\begin{tabular}{|c|c|c|c|}
\hline No. & Program & Nama Ruang & Luasan \\
\hline 1 & Make & Studio Kulit & $1473 \mathrm{~m}^{2}$ \\
\hline 2 & Show & Area Pameran & $1173 \mathrm{~m}^{2}$ \\
\hline 3 & \multirow{7}{*}{ Share } & Area Workshop & $394 \mathrm{~m}^{2}$ \\
\hline 4 & & Coworking Area & $739 \mathrm{~m}^{2}$ \\
\hline 5 & & Kafe & $283 \mathrm{~m}^{2}$ \\
\hline 6 & & Retail & $500 \mathrm{~m}^{2}$ \\
\hline 7 & & Toko Buku & $275 \mathrm{~m}^{2}$ \\
\hline 8 & & Perpustakaan & $438 \mathrm{~m}^{2}$ \\
\hline 9 & & Area Pengelola & $80 \mathrm{~m}^{2}$ \\
\hline 10 & \multirow[t]{2}{*}{ Service } & Area Servis & $686 \mathrm{~m}^{2}$ \\
\hline 11 & & Area Parkir & $3550 \mathrm{~m}^{2}$ \\
\hline
\end{tabular}

Sumber: Penulis, 2019 


\section{Tapak}

Tapak berada di Jl Kemang Raya 8 RT13, RW1, Bangka, Mampang Prapatan, Jakarta Selatan dengan luas tanah $10.000 \mathrm{~m}^{2}$ yang memiliki zonasi perkantoran dagang dan jasa. Tapak berada pada jalan arteri dan dikelilingi pertokoan dan perumahan.

Tabel 3. Kondisi Tapak

\begin{tabular}{ccc}
\hline & Desain Program & Ketentuan \\
\hline KDB (Koefisien Dasar bangunan) & $4.923 \mathrm{~m}^{2}(48 \%)$ & $5.067 \mathrm{~m}^{2}(50 \%)$ \\
\hline KTB (Koefisien Tapak Basement) & $4.923 \mathrm{~m}^{2}(48 \%)$ & $5.067 \mathrm{~m}^{2}(50 \%)$ \\
\hline KLB (Koefisien Lantai Bangunan) & $14.668 \mathrm{~m}^{2}(1,4)$ & $15.201 \mathrm{~m}^{2}(1,5)$ \\
\hline KDH (Koefisien Dasar Hijau) & $3.600 \mathrm{~m}^{2}(35 \%)$ & $3.546 \mathrm{~m}^{2}(35 \%)$ \\
\hline
\end{tabular}

Sumber: olahan penulis, 2019

\section{Gubahan massa}

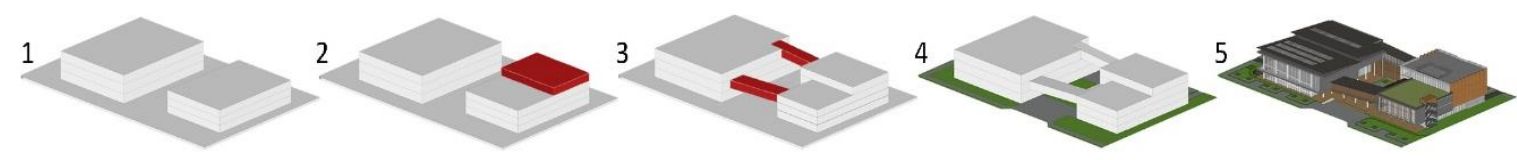

Gambar 6. Gubahan Massa

Sumber: Penulis, 2019

a. Gubahan massa utama mengikuti bentuk tapak dan garis sempadan bangunan (GSB),

b. Penambahan lantai bangunan menyesuaikan kebutuhan ruang,

c. Penambahan jembatan sebagai penghubung kedua massa bangunan,

d. Penambahan area pejalanan kaki menuju entrance utama dan inner court sebagai area penerimaan,

e. Pembentukan fasad menyesuaikan pencahayaan alami dan kebutuhan ruang.

\section{Sirkulasi Tapak dan Bangunan}

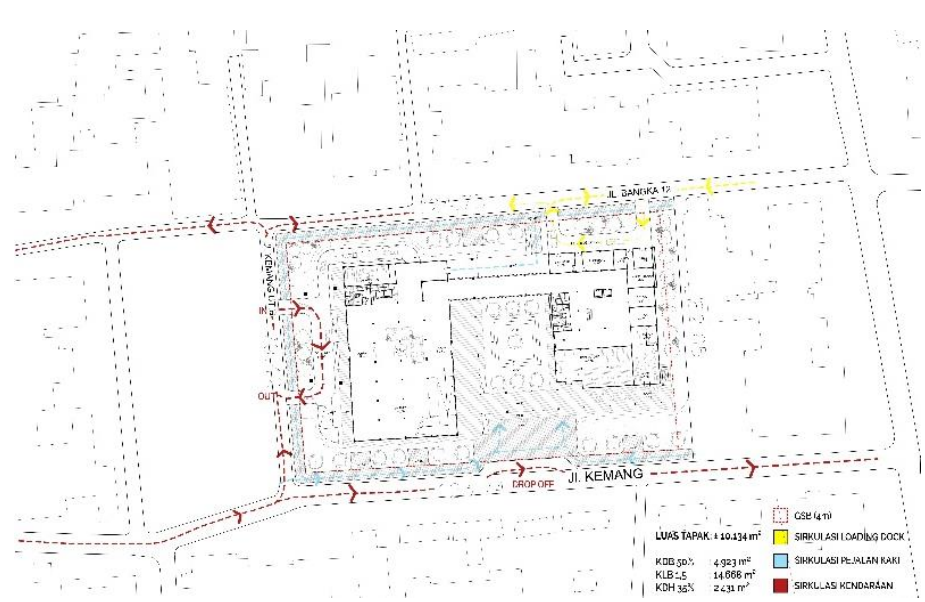

Gambar 7. Siteplan

Sumber: Penulis, 2019

Mulai bulan Mei 2019, Kawasan Kemang akan dirancang menjadi kawasan pejalan kaki. Melihat lingkungan yang mayoritas pertokoan dan intensitas penjalan kaki di Kemang cukup banyak, penulis memfokuskan entrance utama adalah untuk pejalan kaki. Dapat dilihat pada gambar diatas, jalur warna biru merupakan jalur pejalan kaki yang sekaligus merupakan entrance utama berada langsung menghadap ke jalan raya. Diberikan pocket untuk drop off. 
Entrance utama mudah dicapai dan langsung terlihat oleh pejalan kaki dari halte bus. Sedangkan jalur warna merah merupakan jalur mobil dan jalur kuning adalah jalur servis.

Pada entrance utama disambut langsung dengan inner court sekaligus untuk menarik pejalan kaki masuk kedalam bangunan. sirkulasi dalam bangunan yang diterapkan merupakan sirkulasi menerus (cycle) agar pengunjung dapat menjelajahi seluruh ruangan dan kegiatan yang disajikan. Namun disediakan juga akses langsung untuk pengguna khusus dengan system vertical tangga dan lift.

\section{Denah dan Pembagian Ruang}


Gambar 8. Denah Perancangan

Sumber: Penulis, 2019

Perencanaan pada proyek dilakukan dengan pembagian zonasi per lantai berdasarkan alur kegiatan dan hubungan antar ruangnya. Pada lantai dasar terdapat area inner court sebagai area penerimaan, area drop off, dan lobi utama yang langsung tersambung dengan area informasi dan ruang duduk. Entrance mobil berada di sisi kiri bangunan, entrance utama pejalan kaki berada dibagian depan bangunan dan ada site entrance dibagian belakang bangunan yang dapat di akses oleh perumahan/permukiman sekitar. Juga terdapat retail seperti kafe dan toko buku di massa bagian kanan karena kegiatan di lantai dasar merupakan kegiatan yang bersifat publik, sehingga dapat mengundang pengunjung. Sirkulasi pada bangunan bersifat menerus dengan menggunakan ramp yang sekaligus sebagai showcase area tempat memamerkan hasil produk kerajinan kulit. Dengan adanya ramp, pengunjung dapat menikmati karya seni sekaligus menjelajahi seluruh ruangan dan mengikuti seluruh kegiatan yang ada, namun ada akses langsung untuk para disabilitas melalui lift dan tangga.

Lantai dua dapat dicapai melalui ramp sambal melihat karya seni dan juga dimanfaatkan sebagai reading lounge sehingga perjalanan tidak bosan menuju shopping area, tempat membeli produk kerajinan kulit yang dipamerkan serta bisa menuju retail-retail lainnya dan area coworking space tempat untuk siapa pun dapat belajar dan berkerja disana. Sesuai dengan kebutuhan generasi milenial terutama di Kemang.

Menuju ke lantai tiga melalui ramp yang masih berisi karya seni dan reading lounge menuju perpustakaan, area workshop dan kelas-kelas pelatihan non formal sehingga pengunjung dapat belajar mengenai kerajinan kulit dan dapat melihat proses pembuatan produk kulit langsung di studio kulitnya.

Sedangkan untuk lantai empat hanya berisi studio kulit yang lebih privat sehingga tidak semua orang dapat mengaksesnya. Hanya yang berkerja disana ataupun komunitas pengerajin kulit yang berada disana sehingga lebih bersifat privat. Akses menuju ke lantai empat dapat 
menggunakan tangga dan lift dan tidak dapat diakses dengan ramp sehingga tidak bertabrakan dengan sirkulasi pengunjung.

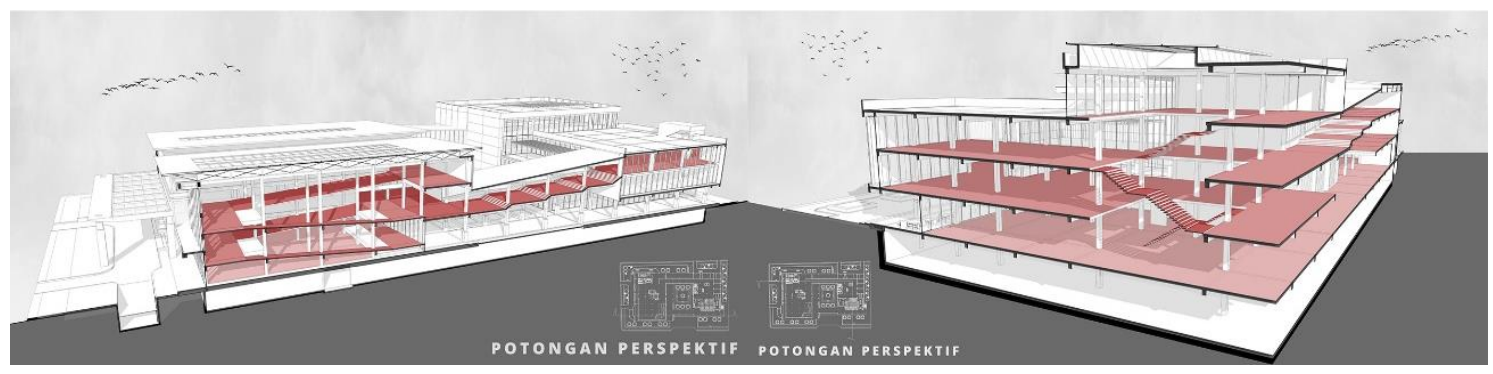

Gambar 9. Potongan Perspektif

Sumber: Penulis, 2019

\section{Struktur}

Struktur bangunan menyesuaikan dengan besar dan tinggi bangunan. bentuk dasar bangunan berupa kotak dan modul kolom mengikuti bentuk tapak. Jarak antar kolom 8 meter $\mathrm{x}$ 6 meter dengan bahan beton bertulang. Ukuran kolom $40 \mathrm{~cm} \times 40 \mathrm{~cm}$ namun ada beberapa kolom di massa kiri dengan ukuran $40 \mathrm{~cm} \times 80 \mathrm{~cm}$ untuk menopang lantai tiga dan atap. Kolom berbahan beton bertulang dengan bentuk persegi. Balok berukuran $30 \mathrm{~cm} \times 60 \mathrm{~cm}$. ketebalan dinding core $20 \mathrm{~cm}$ yang digunakan pada basement.

\section{KESIMPULAN DAN SARAN}

Proyek ini diajukan sebagai pemikiran solusi terhadap permasalahan kawasan dan potensi yang ada. Diharapkan dengan adanya Sentra Kerajinan Kulit di Kemang ini dapat meningkatkan nilai jual produk kulit buatan lokal sehingga potensi industri kerajinan kulit di Indonesia dapat dimaksimalkan dan pengerajin-pengerajin kulit lebih sejahtera serta dapat menjawab rumusan permasalahan yang ada. Juga dapat meningkatkan apresiasi masyarakat terhadap produk kulit dan produk buatan lokal. Selain itu, dengan hadirnya proyek ini dapat melengkapi Kawasan kemang sebagai kawasan industri kreatif dan meningkatkan industri kerajinan (kriya) sehingga secara tidak langsung ikut membangun Jakarta yang lebih berkarakter melalui generasi milenial dalam mengembangkan ekonomi, social, dan budaya dalam bidang industri kreatif khususnya kerajinan kulit.

\section{REFERENSI}

Indonesia Kreatif. (2018). Definisi Industri Kreatif. Retrieved Januari 2019, from http://www.indonesiakreatif.net/index.php/id/page/read/definisi-industri-kreatif

Berita Satu. (2016). KUR Ekonomi Kreatif dan Startup. Retrieved Januari 2019. from https://id.beritasatu.com/home/kur-ekonomi-kreatif-dan-startup/151211

Burke, J. (2014). Makerspace: A Practical Guide for Librarians. United Kingdom: Rowman \& Littlefield.

Hariansyah, M. (2018). Millenials "Bukan Generasi Micin". Jakarta: Gramedia

Katadata. (2018). 71 Persen Penduduk Jakarta merupakan Usia Produktif. Retrieved Januari 2019, from https://databoks.katadata.co.id/datapublish/2018/08/01/71-persen-pendudukjakarta-merupakan-usia-produktif

Lee, C., \& Jacoby, S. (2011). Typological Urbanism and The idea of The City. London: Wiley Media Indonesia. (2017). Mengenal Generasi Milenial, Penentu Masa Depan Bangsa. Retrieved Januari 2019, from http://mediaindonesia.com/read/detail/124559-mengenal-generasimilenial-penentu-masa-depan-indonesia 
Raharjo, T. (2009). Bisnis Seni Kerajinan Bikin Londho Keranjingan, Kewirausahaan Bidang Seni Kriya. Yogyakarta: Program Pascasarjana ISI.

Saraswati. (1996). Seni Mengempa Kulit. Jakarta: Bhratara.

Shen, M. (2016). The Architectural Drawing Foundation. USYD: Australia

Sunarto. (2001). Pengetahuan Bahan Kulit untuk Seni dan Industri. Yogyakarta: Kanisius Tsukamoto, Y., \& Kaijima, M. (2010). Behaviour. New York: Rizzoli.

Zuhdi, B.M. (11)Kriya-Kulit.pdf. Diunduh pada Januari 2019 